DEMOGRAPHIC RESEARCH

VOLUME 30, ARTICLE 23, PAGES 671-702

PUBLISHED 7 MARCH 2014

http://www.demographic-research.org/Volumes/Vol30/23/

DOI: 10.4054/DemRes.2014.30.23

Research Article

Long-term trends of men's co-residence with children in England and Wales

\title{
Ursula Henz
}

\section{(C) 2014 Ursula Henz.}

This open-access work is published under the terms of the Creative Commons Attribution NonCommercial License 2.0 Germany, which permits use, reproduction \& distribution in any medium for non-commercial purposes, provided the original author(s) and source are given credit.

See http:// creativecommons.org/licenses/by-nc/2.0/de/ 


\section{Table of Contents}

$\begin{array}{lll}1 & \text { Introduction } & 672\end{array}$

$2 \quad$ Background 674

$2.1 \quad$ General trends of living with one's own dependent children 674

2.2 Differences by education 676

$\begin{array}{lll}2.3 & \text { Differences by ethnic groups } & 677\end{array}$

$3 \quad$ Data and methods 378

3.1 Data 678

$\begin{array}{lll}3.2 & \text { Variables } & 679\end{array}$

$\begin{array}{lll}3.2 .1 & \text { Parent-child co-residence } & 679\end{array}$

$\begin{array}{lll}3.2 .2 & \text { Ethnicity } & 681\end{array}$

3.2.3 Education 682

3.3 Deriving age-cohort estimates from the LS 682

$4 \quad$ Results 685

4.1 Co-residence with a dependent child up to 18 years of age 685

4.2 Co-residence with three or more own dependent children 686

4.3 Differences by level of education 687

4.4 Differences by ethnicity 690

5 Conclusions 693

$6 \quad$ Acknowledgements $\quad 695$

$\begin{array}{ll}\text { References } & 696\end{array}$

$\begin{array}{ll}\text { Appendix } & 701\end{array}$ 


\title{
Long-term trends of men's co-residence with children in England and Wales
}

\author{
Ursula Henz ${ }^{1}$
}

\begin{abstract}
BACKGROUND

Increasing numbers of childless men as well as fathers with reduced or no contact with their children have sparked concern about an erosion of fatherhood. Although the general trend is undisputed, claims about men's decreasing family involvement lack a sound empirical basis that enables comparisons between countries and sub-groups of society.
\end{abstract}

\section{OBJECTIVE}

This study derives long-term trends in father-child co-residence over the life course in England and Wales, and provides comparisons of these trends by level of education and ethnic origin.

\section{METHODS}

The paper calculates shares of father-child co-residence from the National Statistics Longitudinal Study (LS) and the British Labour-Force Surveys (LFS).

\section{RESULTS}

There has been a decline of father-child co-residence in England and Wales for men in their thirties, an even greater decline for men in their twenties, and a small increase in the shares of father-child co-residence at higher ages. The trends for different educational groups were similar, but men with a degree had particularly low rates of father-child co-residence at younger ages, and relatively high ones at older ages. Neither less-educated men, nor men from Black-Caribbean and Black-African origins showed rates of father-child co-residence as low as one might have expected.

\section{CONCLUSIONS}

The steady decline of father-child co-residence among men born between 1930 and 1979 in England and Wales lends support to claims about an erosion of fatherhood. However, it is unwarranted to generalize findings from other countries about

\footnotetext{
${ }^{1}$ London School of Economics, United Kingdom. E-Mail: U.Henz@1se.ac.uk.
} 
particularly low levels of father-child co-residence among less-educated men to men in England and Wales.

\section{Introduction}

In all developed societies, the Second Demographic Transition (Lesthaeghe 1995, van de Kaa 1987) has changed the structure of men and women's life courses. Among the outcome of these transformations are the declining proportions of men living with children of their own, and the shrinking number of years of life that men live with their children. These trends have been well documented for the United States (Eggebeen and Uhlenberg 1985, King 1999, Eggebeen 2002, Goldscheider, Hogan, and Bures 2001, Hogan and Goldscheider 2001). In addition, Jensen $(1998,1999)$ has presented data for a number of European countries - excluding Britain - about the low shares of men in their twenties living with children.

The drop in father-child co-residence is one of main bases of claims about 'fathers pulling out of family life' (George and Gold 1991) and of 'shrinking fatherhood' (Jensen 1999). These claims have been linked to a number of problems at the individual and the societal level. A comprehensive body of literature has studied the potentially negative consequences of father absence for child development and well-being (Amato 2000; Lamb 2010). More recently there have been investigations into how fatherhood affects men's own well-being. The few studies addressing this issue indicated a better social integration and closer family ties of fathers (Eggebeen and Knoester 2001; Keizer, Dykstra, and Poortman 2010). Furthermore, it has been argued that a decreasing involvement of fathers in bringing up their children leads to an increased burden on women, who have to shoulder their stronger labour-market engagement without relief from their roles in the home (Jensen 1999). On the societal level, the concerns about increasing numbers of men not living with children of their own are related to claims of a polarization of society into a declining family sector and a diverse non-family sector (Daly 2005). The problems of combining full employment with bringing up children make families more economically vulnerable than childless individuals. With decreasing numbers of parents among employees, this raises fears that work-place culture might become less family friendly. Finally, more general concerns have been raised; for example, that a shrinking child-oriented sector of society might lead to less emphasis upon the interests of children in political agendas (Jensen 1995) or how more and more widespread childless lifestyles affect societal visions of solidarity in the future (Rupp 2009). 
Given the number of concerns associated with 'shrinking fatherhood', we know surprisingly little about the exact trends in fathers' involvement in their families, in Britain and in many other countries. One reason for this is the problem of obtaining reliable information about men's fertility histories (Rendall et al. 1999), making it difficult to calculate rates of childlessness in men. In addition, men's parenthood experiences have been affected by trends in partnership breakup and new family forms. Reliable data about these processes from men's perspective are also difficult to obtain. The only available data that provide some information about long-term trends in men's involvement with children are about father-child co-residence. Co-residential fatherhood offers the most opportunities for father-child interaction, and has welldocumented effects on a child's wellbeing (Lamb 2010). Therefore, long-term trends in father-child co-residence offer an approximate account of changes in the prevalence of the arguably most intensive experience of fatherhood.

As mentioned earlier, the most detailed analyses of father-child co-residence have been presented for the United States. Eggebeen and Uhlenberg's (1985) study of the United States in the 1960s and 1970s showed that the drop in men's co-residence with children over time was pervasive across educational levels and racial categories. Eggebeen (2002) also reported that the experience of men living with their own children became more concentrated in middle age, especially among highly educated men. The decline in the number of men living with three or more children of their own turned out to be particularly strong (Eggebeen 2002).

Jensen's (1998) research only drew on rates of father-child co-residence for men in two particular age groups. Therefore, this analysis did not fully consider that a decline in father-child co-residence at young adult ages might have been compensated for by higher rates of father-child co-residence at higher ages, resulting in a temporal shift but not necessarily indicating a decline. A life course perspective can provide a more comprehensive assessment of trends in 'shrinking fatherhood'.

This study will examine cohort trends in men's co-residence with children over the life course. These long-term trends in father-child co-residence in England and Wales have not been documented before this. The results will be examined to determine whether different phases of the life course show different trends and whether the pace of change has slowed in the recent past. In addition, the study examines differences in these trends between educational and ethnic groups. Quite notably, Daly's (2005) conclusion that 'the upper income groups are increasingly less children-oriented and the presence of children is ever more closely associated with social class position' was based on patterns among women, which can differ from those of men. Past research has also shown strong variations in fertility between women from different ethnic groups. Research on men from different ethnic origins living with children was limited to 
particular points in time and particular ages, which provides an incomplete account of their experiences. This study aims to fill this gap.

This study presents age-specific groups of fathers living with their children by analyzing the National Statistics Longitudinal Study (LS) and the British Labour Force Surveys (LFS). We focus on co-residence with a father's own dependent children up to age 18 because it is most normatively associated with a certain amount of involvement and responsibility of fathers. We also show trends in living with a larger number of children. This paper presents cohort comparisons for ten-year birth cohorts from 1930-39 to 1970-79, and examines variations in the observed patterns by education and ethnicity.

\section{Background}

The long-term trends in father-child co-residence in England and Wales are aggregated outcomes of several demographic trends. We limit the following discussion to the main underlying processes. We first discuss general trends in men's fertility rates, shifts in the timing of becoming a father, and trends in men not living with their children. We then address differences between educational and ethnic groups. If there is little information about men's demographic trends, we will resort to studies of corresponding processes for women to derive hypotheses about the trends in men living with their children.

\subsection{General trends of living with one's own dependent children}

In England and Wales, the number of childless women has increased from just nine per cent for women born in 1946, to 20 per cent for women born in the first half of the 1960s (ONS 2013). Estimates of male childlessness tend to be higher than of female childlessness (Kneale and Joshi 2008; Kiernan 1989). This is not just because of the underreporting of men's children (Rendall et al. 1999) but it has also been linked to a lower desire of men to have children (Jensen 1999). A higher share of childless men than women can also reflect the stronger tendency among men to have children with more than one partner in their lifetime (Skrede 2005; Beaujouan 2012). All these findings suggest that, in each subsequent birth cohort, the share of childless men has increased, and that there was no indication of the trend slowing down before the 1960 birth cohorts.

Different phases of the life course might display different trends. Most developed countries have seen a postponement of family formation over the last few decades 
(Billari, Liefbroer, and Philipov, 2006). There is some evidence that men have postponed their first child more than women have (Kneale and Joshi 2008). In addition, the trend of having smaller families (ONS 2013) should have reduced the total time that men lived with their children over successive birth cohorts, if the spacing of children did not change. Taken together, these trends suggest that men's experience of living with an own dependent child will be more concentrated in midlife.

Since the 1970s, increasing numbers of men have lived away from their children. One reason for this trend was the rising number of births out of wedlock (ONS 2009, O'Leary et al. 2010). The majority of these children were born to cohabiting couples, but the lower stability of non-marital unions meant that these fathers faced a higher risk than did married fathers of living away from their children at some point in their lives. In addition, the percentage of children born to single mothers also increased considerably from the 1970s until the early 1990s, and has been stable since then (O'Leary et al. 2010). Finally, the rising divorce rate since the 1970s meant that more married fathers stopped living with their children (ONS 2012c). Whereas children used to have a stabilizing effect on marriages, they have been found to increase divorce risks in more recent analyses (Chan and Halpin 2003). In the past, custody of children was usually awarded to mothers (Haskey 1996b) and most children stayed with their mothers after divorce. Overall, the trend of fathers living away from their children will have reduced father-child co-residence, in particular from the 1970s onwards, which is for the 1940s cohorts and later.

Relevant to both the timing and the levels of men living with their children is the option of forming a new family after a divorce or separation. In some countries, there is evidence that divorced fathers re-partner to a higher extent than divorced mothers (Goldscheider and Sassler 2006; Beaujouan 2012) and we would also expect this to be the case in Britain. As 30 per cent of separated women with one child went on to have a child with a new partner in Britain, and 10 to 20 per cent of women with a higher number of children from their earlier marriage subsequently re-partnered (Jeffries, Berrington, and Diamond 2000), the trend of forming second families might also have a considerable effect on father-child co-residence among middle-aged men. Taken together, we hypothesize that:

H1. The shares of men living with their children will have decreased over successive birth cohorts.

H2. The shares of men living with three or more children will have decreased over successive birth cohorts.

H3. Men's rates of living with their children will have decreased profoundly in early adulthood. 
Beyond early adulthood, the share of men living with their children has been subject to opposing trends: a declining trend from increasing childlessness, having smaller families and union separation will have been balanced to some extent by recuperation from postponement at younger ages and forming second families. As the information about these diverse trends is fragmentary, we abstain from formulating any particular hypothesis about the aggregate trends at these ages.

\subsection{Differences by education}

Earlier research has shown considerable differences in fertility rates between women with different levels of education. In particular, highly educated women markedly postpone first births, whereas the trend was much weaker among less educated women (Rendall et al. 2005; Kneale and Joshi 2008). When comparing the 1958 and 1970 birth cohorts, Kneale and Joshi observed that the postponement of first births was considerably more likely for men than for women, and particularly likely for men with a tertiary education. When it comes to explaining the postponement of first births, Bhrolchain and Beaujouan (2012) have provided strong evidence that a prolonged stay in the education system is a major cause for women postponing first births. Another explanation has been put forward by Blossfeld and his team (2005) who suggested that childbirth postponement is a reaction to increasing uncertainty in life, making it more difficult to establish stable partnerships and stable labour-market positions. The latter explanation might be even more important for men than for women, since, among other reasons, Britain conforms to a strong male-breadwinner regime. Francesconi and Golsch (2005) have shown that British school leavers with low educational and occupational qualifications tend to be more often confronted with uncertainty about their future careers than those with longer educational careers. They also found that young men in temporary and part-time employment stayed longer in cohabiting unions instead of marrying, which in turn was associated with lower rates of entry into parenthood. Overall these arguments suggest that both highly-educated and lesseducated men postponed their first childbirths.

Because there is no age limit for men to become fathers, postponing childbirth could indicate for men more often than for women just a temporal shift of childbirth and less often a process that ends in forgoing biological parenthood altogether. In particular, highly educated fathers tend to enjoy more stable careers, whereas men with lower levels of education have faced a difficult labour market since the 1970s. For these reasons, one could expect that co-residence with a dependent child after the father reaches age 40 might have increased in time with postponement, particularly for highly educated men. 
In addition, the chances of living away from their children might differ between men with different levels of education. British studies about differences in the formation of non-marital cohabiting unions (Ermish 2005) and union dissolution (Berrington and Diamond 1999, Chan and Halpin 2003, Steele et al. 2007) by level of education for women have reported positive effects of education on these events, or no effects. We abstain from a detailed review of these diverse findings because the gendered nature of marriage and cohabitation precludes the assumption that exactly the same pattern holds with regard to men's level of education. The only study that directly concerned men living away from their children was carried out by Bradshaw and his coauthors (1999). They remarked that "non-resident fathers are more likely than resident fathers to have left school at younger ages and [...] appear to have low academic or vocational qualifications" (Bradshaw et al. 1999: 47). As they pointed out, the empirical basis of this claim was weak

Overall, such diverse and sometimes weak or contradictory findings do not lead us to any clear hypothesis about differences in men's levels co-residence with their children by men's level of education. The most plausible hypothesis is the following:

H4. The trends in father-child co-residence will have been similar in all educational groups.

\subsection{Differences by ethnic groups}

Finally, we turn to possible differences between ethnic groups. Profiles of ethnic minority populations in Britain have been presented elsewhere (Coleman, Compton, and Salt 2002; Haskey 1996a, 1997; Peach 1996). Minority ethnic groups' fertility rates have differed strongly. Bangladeshi and Pakistani women displayed considerably higher fertility rates than other groups (Coleman and Dubuc 2010). In the 1960s, women from the other main minority groups - Black African, Indian, and Caribbean women - had higher fertility levels than Whites, but these differences decreased for all groups except for women of Black-African origin.

Marriage rates are very high and divorce rates extremely low among men and women of Asian origin (Berrington 1994; Platt 2009). However, there are some differences between Asian groups; for example, the delay of marriage and postponement of childbearing in marriage among men and women of Indian origin, but not among those of Bangladeshi and Pakistani origin. In contrast to these groups, a comparatively low percentage of men and women of Black-Caribbean and BlackAfrican ethnic origins lived with a partner (Berrington 1994; Platt 2009). They also experienced rather high levels of marriage breakdown (Berrington 1994). Berrington 
(1994) and Berthoud (2005) have documented the high prevalence of single-parent families among Black-Caribbean and Black-African women. We hypothesize that:

H5. Men from Indian, Pakistani and Bangladeshi origins will have displayed higher levels of father-child co-residence than men from White origins.

H6. Men from a Black-Caribbean and Black-African origin will have had considerably lower rates of father-child co-residence than men from all other groups.

\section{Data and methods}

\subsection{Data}

These analyses are based on two large sources of data. Earlier time periods are covered by the LS, whereas the most recent data are taken from the LFS. Each data set provides among others information about household composition and the relationships between household members at the different survey years, from which age-and-cohort-specific shares of father-child co-residence can be calculated.

The LS has been compiled by the Office for National Statistics (ONS 2012a). Its original sample was drawn from the 1971 census by selecting all individuals who were born on four specified days of the year. These about half a million individuals were traced in the following census waves from 1981, 1991 and 2001. Other individuals were added to the study if they participated in a later census and were born on any of the four specified days in the year.

The LS has been chosen for this study because it goes back to 1971; its large sample size enables analyses by ethnic groups, and it offers good quality information about ethnicity, even for the earlier waves, through the exploration of the linkage of records over the census waves. By using the same ethnicity variable for all waves, the observed trends will not be vulnerable to changes in the ethnicity measure. The same advantage can be used for measuring education.

The LFS allows one to extend the analyses to more recent years. In addition, using both surveys offers the opportunity to assess the reliability of the findings for the overlapping survey years of 1991 and 2001. We use 24 separate LFS surveys, spread out between 1992 and 2010. After selecting men aged 18 to 69 and women aged 18 to 65 and limiting the data to individuals living in England and Wales at the time of the survey, more than 1.1 million remain for the analyses. The LFS response rate has decreased over time, from levels above 80 percent to 76 per cent in 2003 and 65 per cent in 2010. The response rates among ethnic minority populations might have been 
even lower (Coleman and Smith 2005). The figures presented in this paper are based on weighted data.

Response rates should be less of a problem for the LS because it is taken from the census. However, by using the ethnicity information from the 2001 census, or, if this is not available, the 1991 census, one might introduce a selection bias for the earlier years when using the ethnicity variable, because the analyses are limited to individuals who could be traced in the 1991 or 2001 waves. $^{2}$

For each survey year the analyses use information about all men aged 18 to 69 and all women aged 18 to 65 at the time of the survey. To increase sample sizes, we combined the LFS surveys into three groups: Surveys from 1992 to 1996 reproduced patterns between the 1991 and the 2001 census; LFS surveys from 1997 to 2003 can be compared with the 2001 census, and LFS surveys from 2006 to 2010 indicate the trends early in the new millennium. The three merged groups of LFS surveys will be labeled as LFS92_96, LFS97_03 and LFS06_10.

\subsection{Variables}

\subsubsection{Parent-child co-residence}

This study focuses on co-residence with at least one dependent child, aged 18 or younger, that is classified as the man's or woman's own child. The paper applies the same definition of 'dependent children' as the Office for National Statistics. According to this definition, all children under age 16 are dependent, as well as children between 16 and 18 years of age if they are full-time students.

Both surveys provide indicators that enable us to identify children as a man's or a woman's own child. In the 2001 census and in the LFS surveys since 1996, this information can be obtained directly from household grids that recorded the relationship of all household members to each other. In the earlier years, both surveys only asked about the relationship of all household members to the head of household or the household reference person, that is, the person who provided all household information. Both surveys have used different strategies for identifying children's parents for these

\footnotetext{
${ }^{2}$ Individuals in the earlier census waves who died, are known to have left the country before the 1991 census or were not traceable in the 1991 or 2001 census for other reasons are not included in the analysis of ethnic groups. The Office for National Statistics has carried out two investigations into the census linkage (Blackwell et al. 2003; Hattersely and Creeser 1995). Roughly speaking, about ten per cent of members of the LS study at one census who were not recorded to have died or emigrated before the following census could not be identified in the following census. For immigrants, these figures were higher (ONS 2012b, Table L7181.6).
} 
earlier years. The LFS used interviewer-provided information about family units, whereas the LS applied certain classification rules to the available information. ${ }^{3}$

Respondents to the 2001 LS and the LFS surveys since 1996 were offered a special category for stepchildren. ${ }^{4}$ Earlier census waves and waves of the LFS surveys made no attempt to identify stepchildren. For these years, the child category captures both natural and stepchildren, but it is also possible that some stepchildren might have been reported as unrelated persons. For consistency, we also combine natural children and stepchildren in the later surveys. ${ }^{5}$

Table 1 gives the percentages of men who lived with a dependent child at the time of the different survey years. Of all men aged 18 to 69 , this group has apparently dropped by ten per cent from 41 per cent in 1971 to 31 per cent in recent years. However, the LFS shares are generally about one and a half percentage points lower than the LS estimates, suggesting that the true decline over the years was closer to 8.5 percentage points.

To simplify language, in the remainder of this paper "men's children" will always mean "men's own children" in the above sense, unless stated otherwise. Similarly "living with a child" will be short for "living with one's own child" for the rest of the paper.

\footnotetext{
${ }^{3}$ In some situations, no clear rule could be established. For example, for about one percent of all household members in 1991, a relationship with the LS reference person could not be identified.

${ }^{4}$ According to the $2001 \mathrm{LS}$, the percentage of men living with stepchildren is highest during the early to midthirties, with rates of around 5 per cent but many of these men live also with biological children. The difference between the share of men living with biological children and the share of men living with either step or biological children is small; it is highest when men are in their thirties or early forties at levels close to 2 per cent.

${ }^{5}$ On the one hand, if stepchildren were sometimes reported as unrelated persons, we will underestimate the shares of father-child co-residence. On the other hand, merging natural and stepchildren in the analyses might lead to an overestimation of men's involvement in bringing up children as stepfathers are often less involved in bringing up children than co-resident biological fathers (Barnes et al. 1997).
} 
Table 1: Descriptive statistics for constituent samples of men aged 18 to 69

\begin{tabular}{|c|c|c|c|c|c|c|c|}
\hline & LS1971 & LS1981 & LS1991 & LS2001 & LFS92_96 & LFS97_03 & LFS06_10 \\
\hline$\overline{\mathrm{N}}$ & 150,785 & 152,678 & 157,146 & 149,163 & 95,360 & 220,315 & 134,732 \\
\hline \multicolumn{8}{|l|}{$\begin{array}{l}\text { Per cent living with an own } \\
\text { dependent child aged } 18\end{array}$} \\
\hline $\begin{array}{l}\text { or younger } \\
\text { Per cent living with three } \\
\text { or more own dependent }\end{array}$ & 41.2 & 40.0 & 34.7 & 34.1 & 32.8 & 32.6 & 31.4 \\
\hline \multicolumn{7}{|l|}{ Education (\%) } & 5.4 \\
\hline $\begin{array}{l}\text { No qualification } \\
\text { Sub-degree }\end{array}$ & 47.7 & 42.1 & 34.5 & 28.2 & 34.1 & 29.1 & 26.2 \\
\hline qualification & 31.4 & 35.5 & 42.1 & 48.7 & 44.4 & 46.3 & 44.4 \\
\hline Degree & 20.8 & 22.3 & 23.3 & 23.0 & 21.5 & 24.6 & 29.4 \\
\hline \multicolumn{8}{|l|}{ Ethnicity (\%) } \\
\hline White & 97.3 & 94.9 & 92.7 & 91.1 & 94.1 & 92.8 & 88.8 \\
\hline Indian & 1.0 & 2.0 & 2.5 & 2.8 & 1.8 & 1.9 & 2.6 \\
\hline Pakistani/Bangladeshi & 0.7 & 1.2 & 1.8 & 2.3 & 1.1 & 1.5 & 2.2 \\
\hline Black Caribbean & 0.6 & 0.8 & 0.9 & 0.8 & 1.0 & 1.0 & 1.0 \\
\hline Black African & 0.1 & 0.1 & 0.4 & 0.7 & 0.6 & 0.8 & 1.3 \\
\hline Other & 0.5 & 1.0 & 1.7 & 2.4 & 1.3 & 2.0 & 4.0 \\
\hline
\end{tabular}

\subsubsection{Ethnicity}

The analyses distinguish five ethnic groups: White, Indian, Pakistani and Bangladeshi, Black Caribbean and Black African. As described earlier, in the LS these have been derived from the 2001 census or, if the individual could not be identified in the 2001 wave, the1991 census. In the LFS, the information about ethnicity was collected at each survey wave. Our coding follows the guidelines published by the Economic and Social Data Service (ESDS 2012), which were designed to provide a consistent measure over time. We use the same set of ethnic categories for all years, but some variation in the pre-coded categories in the different survey years, especially regarding mixed ethnicities, might affect the stability of the measure over different survey years in the LFS. Table 1 gives the distribution of ethnicity in the different samples. 


\subsubsection{Education}

The different census waves employed very different measures of education. For this study we use the information about the highest educational qualification from the 2001 census with categories 'no qualifications', 'sub-degree qualification' and 'degree level and above'. The category 'sub-degree qualification' comprises individuals with GCSEs, O-Levels, A-Levels or equivalent. ${ }^{6}$ The same categories have been created in the LFS.

\subsection{Deriving age-cohort estimates from the LS}

A major disadvantage of the LS is the long gap between the census waves. Although this rules out a genuine cohort analysis for our purpose, one can still carry out a synthetic cohort analysis if one assumes that all members of a cohort experience during their life course the same pattern of co-residence as experienced by men at the same ages in a particular year (Eggebeen and Uhlenberg 1985). To study the long-term trends in father-child co-residence in sufficient detail, we compute estimates for the number of fathers living with their children by five-year age groups. Figure 1 gives an overview of the data in the LS. When working with ten-year birth cohorts, any five-year age group only includes half of the cohort members - either those born in the earlier five years or those born in the later five years. For example, when examining individuals aged 41 to 45 in the 1930-39 birth cohort, the LS provides only information for individuals born in 1935 to 1939 , but not for those born 1930 to 1934. Similarly, the age group 36 to 40 in the same cohort only comprises people from the 1930 to 1934 birth years. This exclusion of individuals born in certain years might lead to biased estimates. However, one can derive estimates of the missing age groups by using information for the same age group in adjacent birth years. The shadings of the cells in Figure 2 indicate the particular estimation strategies applied to the different cells. For cells with information available for the two adjacent cells in the same age group, the share of men or women living with their children is estimated as the average of the two adjacent cells ('withinage-group adjustment'):

$$
\hat{x}_{i, j}=\frac{1}{2} *\left(x_{i, j-1}+x_{i, j+1}\right)
$$

\footnotetext{
${ }^{6}$ The measure carries a certain amount of error as a person's highest level of educational qualification might have changed over the life course. We only show figures relating to age 21 and older for respondents with a degree.
} 
The resulting estimate for the full ten-year birth cohort is calculated as the average of the share in the observed five-year group and the above estimate. For example, using the notation in Figure 2, the share of 41-to-45-year old men in the 1930-39 cohort who lived with their children is estimated as

$$
\frac{1}{2} *\left(\hat{x}_{6,7}+x_{6,8}\right)=\frac{1}{2}\left(1 / 2 *\left(x_{6,6}+x_{6,8}\right)+x_{6,8}\right)=0.75 * x_{6,8}+0.25 * x_{6,6}
$$

Deriving estimates for the remaining cells with missing information is less straightforward because there are several plausible strategies. The estimates shown in this paper assume that within a birth cohort, the shares in two age groups will differ by the same factor, for example

$$
\frac{\hat{x}_{2,9}}{x_{3,9}}=\frac{x_{2,10}}{\hat{x}_{3,10}} \text {, or } \hat{x}_{2,9}=x_{3,9} * x_{2,10} / \hat{x}_{3,10}
$$

Using the within-age-group-adjusted estimator for $\mathrm{x}_{3,10}$ leads to

$$
\hat{x}_{2,9}=\frac{x_{3,9} * x_{2,10}}{0.5 * x_{3,9}+0.5 * x_{3,11}}
$$

and the estimate for the share of 21-to-25-year old men in the 1940-49 birth cohort of living with a child is calculated as mean of $\hat{\mathrm{x}}_{2,9}$ and $\mathrm{x}_{2,10}$.

The resulting estimates should be good approximations of the true shares if change happened gradually. We believe that this is a plausible assumption, given the small amount of change in father-child co-residence following, for example, the profound change in British divorce law in 1969. Therefore, our confidence in estimates for the 'inner' cells in Figure 2 is high. As there are other plausible ways of calculating the estimators for the 'outer' cells, the obtained values are less certain. Appendix Figure A1 gives the prevalence of father-child co-residence with a dependent child aged 18 or younger before the adjustment. A comparison with the adjusted shares in Figure 3 shows a very strong similarity of the two patterns. 
Henz: Long-Term Trends of Men's Co-residence with Children in England and Wales

Figure 1: Data matrix by five-year birth cohorts and five-year age groups, indicating cells covered in the four LS waves (shaded) and not covered (not shaded)

\begin{tabular}{|c|c|c|c|c|c|c|c|c|c|c|c|c|c|c|c|c|c|c|}
\hline & \multicolumn{2}{|c|}{ 1900-09 } & \multicolumn{2}{|c|}{ 1910-19 } & \multicolumn{2}{|c|}{ 1920-29 } & \multicolumn{2}{|c|}{ 1930-39 } & \multicolumn{2}{|c|}{$1940-49$} & \multicolumn{2}{|c|}{$1950-59$} & \multicolumn{2}{|c|}{$1960-69$} & \multicolumn{2}{|c|}{$1970-79$} & \multicolumn{2}{|c|}{ 1980-89 } \\
\hline & $\begin{array}{l}00- \\
04\end{array}$ & $\begin{array}{l}05- \\
09\end{array}$ & $\begin{array}{l}10- \\
14\end{array}$ & $\begin{array}{l}15- \\
19\end{array}$ & $\begin{array}{l}20- \\
24\end{array}$ & $\begin{array}{l}25- \\
29\end{array}$ & $\begin{array}{l}30 \text { - } \\
34\end{array}$ & $\begin{array}{l}35- \\
39\end{array}$ & $\begin{array}{l}40- \\
44\end{array}$ & $\begin{array}{l}45- \\
49\end{array}$ & $\begin{array}{l}50- \\
54\end{array}$ & $\begin{array}{l}55- \\
59\end{array}$ & $\begin{array}{l}60- \\
64\end{array}$ & $\begin{array}{l}65- \\
69\end{array}$ & $\begin{array}{l}70- \\
74\end{array}$ & $\begin{array}{l}75- \\
79\end{array}$ & $\begin{array}{l}80- \\
84\end{array}$ & $\begin{array}{l}85- \\
89\end{array}$ \\
\hline 18-20 & & & & & & & & & & & $X_{1,11}$ & $X_{1,12}$ & $X_{1,13}$ & $X_{1,14}$ & $X_{1,15}$ & $X_{1,16}$ & $X_{1,17}$ & $X_{1,18}$ \\
\hline $21-25$ & & & & & & & & & $\mathrm{X}_{2,9}$ & $X_{2,10}$ & $X_{2,11}$ & $X_{2,12}$ & $X_{2,13}$ & $X_{2,14}$ & $X_{2,15}$ & $X_{2,16}$ & & \\
\hline $26-30$ & & & & & & & & & $X_{3,9}$ & $X_{3,10}$ & $X_{3,11}$ & $X_{3,12}$ & $X_{3,13}$ & $X_{3,14}$ & $X_{3,15}$ & $X_{3,16}$ & & \\
\hline $31-35$ & & & & & & & $\mathrm{X}_{4,7}$ & $\mathrm{X}_{4,8}$ & $\mathrm{X}_{4,9}$ & $X_{4,10}$ & $\mathrm{X}_{4,11}$ & $\mathrm{X}_{4,12}$ & $X_{4,13}$ & $\mathrm{X}_{4,14}$ & & & & \\
\hline $36-40$ & & & & & & & $X_{5,7}$ & $X_{5,8}$ & $x_{5,9}$ & $X_{5,10}$ & $X_{5,11}$ & $X_{5,12}$ & $X_{5,13}$ & $X_{5,14}$ & & & & \\
\hline \begin{tabular}{|l|}
$41-45$ \\
\end{tabular} & & & & & $X_{6,5}$ & $\mathrm{X}_{6,6}$ & $\mathrm{X}_{6,7}$ & $X_{6,8}$ & $X_{6,9}$ & $\mathrm{X}_{6,10}$ & $X_{6,11}$ & $\mathrm{X}_{6,12}$ & & & & & & \\
\hline 46-50 & & & & & $x_{7,5}$ & $\mathrm{X}_{7,6}$ & $\mathrm{X}_{7,7}$ & $\mathrm{X}_{7,8}$ & $\mathrm{X}_{7,9}$ & $\mathrm{X}_{7,10}$ & $x_{7,11}$ & $\mathrm{X}_{7,12}$ & & & & & & \\
\hline $51-55$ & & & $\mathrm{X}_{8,3}$ & $X_{8,4}$ & $\mathrm{X}_{8,5}$ & $\mathrm{X}_{8,6}$ & $\mathrm{X}_{8,7}$ & $\mathrm{X}_{8,8}$ & $X_{8,9}$ & $x_{8,10}$ & & & & & & & & \\
\hline $56-60$ & & & $x_{9,3}$ & $X_{9,4}$ & $x_{9,5}$ & $X_{9,6}$ & $X_{9,7}$ & $X_{9,8}$ & $x_{9,9}$ & $X_{9,10}$ & & & & & & & & \\
\hline \begin{tabular}{|l|}
$61-65$ \\
\end{tabular} & $X_{10,1}$ & $\mathrm{X}_{10,2}$ & $X_{10,3}$ & $\mathrm{X}_{10,4}$ & $\mathrm{X}_{10,5}$ & $\mathrm{X}_{10,6}$ & $\mathrm{X}_{10,7}$ & $\mathrm{X}_{10,8}$ & & & & & & & & & & \\
\hline 66-69 & $X_{11,1}$ & $\mathrm{X}_{11,2}$ & $X_{11,3}$ & $\mathrm{X}_{11,4}$ & $\mathrm{X}_{11,5}$ & $\mathrm{X}_{11,6}$ & $\mathrm{X}_{11,7}$ & $\mathrm{X}_{11,8}$ & & & & & & & & & & \\
\hline
\end{tabular}

$1971 \quad 1981 \quad 2001$

Figure 2: Schematic overview over rules for estimating shares for age-cohort analyses for men

\begin{tabular}{|c|c|c|c|c|c|c|c|c|c|c|c|c|c|c|c|c|c|}
\hline & \multicolumn{2}{|c|}{ 1900-09 } & \multicolumn{2}{|c|}{ 1910-19 } & \multicolumn{2}{|c|}{$1920-29$} & \multicolumn{2}{|c|}{ 1930-39 } & \multicolumn{2}{|c|}{ 1940-49 } & \multicolumn{2}{|c|}{ 1950-59 } & \multicolumn{2}{|c|}{ 1960-69 } & \multicolumn{2}{|c|}{ 1970-79 } & 1980-89 \\
\hline & $\begin{array}{l}00- \\
04\end{array}$ & $\begin{array}{l}05- \\
09\end{array}$ & $\begin{array}{l}10- \\
14\end{array}$ & $\begin{array}{l}15- \\
19\end{array}$ & $\begin{array}{l}20- \\
24\end{array}$ & $\begin{array}{l}25- \\
29\end{array}$ & $\begin{array}{l}30- \\
34\end{array}$ & $\begin{array}{l}35- \\
39\end{array}$ & $\begin{array}{l}40- \\
44\end{array}$ & $\begin{array}{l}45- \\
49\end{array}$ & $\begin{array}{l}50- \\
54\end{array}$ & $\begin{array}{l}55- \\
59\end{array}$ & $\begin{array}{l}60- \\
64\end{array}$ & $\begin{array}{l}65- \\
69\end{array}$ & $\begin{array}{l}70- \\
74\end{array}$ & $\begin{array}{l}75- \\
79\end{array}$ & $\begin{array}{ll}80- & 85- \\
84 & 89\end{array}$ \\
\hline \begin{tabular}{|l|}
$18-20$ \\
\end{tabular} & & & & & & & & & & & $\mathrm{X}_{1,11}$ & $X_{1,12}$ & $\mathrm{X}_{1,13}$ & $\mathrm{X}_{1,14}$ & $\mathrm{X}_{1,15}$ & $X_{1,16}$ & $\mathrm{X}_{1,17} \quad \mathrm{X}_{1,18}$ \\
\hline 21-25 & & & & & & & & & $x_{2,9}$ & $X_{2,10}$ & $X_{2,11}$ & $X_{2,12}$ & $X_{2,13}$ & $\mathrm{X}_{2,14}$ & $X_{2,15}$ & $X_{2,16}$ & \\
\hline $26-30$ & & & & & & & & & $\mathrm{X}_{3,9}$ & $X_{3,10}$ & $\mathrm{X}_{3,11}$ & $X_{3,12}$ & $X_{3,13}$ & $\mathrm{X}_{3,14}$ & $X_{3,15}$ & $x_{3.16}$ & \\
\hline $31-35$ & & & & & & & $x_{4,7}$ & $\mathrm{X}_{4,8}$ & $X_{4,9}$ & $\mathrm{X}_{4,10}$ & $X_{4,11}$ & $\mathrm{X}_{4,12}$ & $\mathrm{X}_{4,13}$ & $\mathrm{X}_{4,14}$ & & & \\
\hline $36-40$ & & & & & & & $X_{5,7}$ & $X_{5,8}$ & $X_{5,9}$ & $X_{5,10}$ & $X_{5,11}$ & $X_{5,12}$ & $X_{5,13}$ & $X_{5.14}$ & & & \\
\hline 41-45 & & & & & $X_{6,5}$ & $X_{6,6}$ & $X_{6,7}$ & $X_{6,8}$ & $x_{6,9}$ & $X_{6,10}$ & $X_{6,11}$ & $X_{6,12}$ & & & & & \\
\hline \begin{tabular}{|l|}
$46-50$ \\
\end{tabular} & & & & & $\mathrm{X}_{7,5}$ & $\mathrm{X}_{7,6}$ & $\mathrm{X}_{7,7}$ & $X_{7,8}$ & $\mathrm{X}_{7,9}$ & $X_{7,10}$ & $\mathrm{X}_{7,11}$ & $x_{7,12}$ & & & & & \\
\hline $51-55$ & & & $X_{8,3}$ & $\mathrm{X}_{8,4}$ & $\mathrm{X}_{8,5}$ & $\mathrm{X}_{8,6}$ & $X_{8,7}$ & $\mathrm{X}_{8,8}$ & $\mathrm{X}_{8,9}$ & $\mathrm{X}_{8,10}$ & & & & & & & \\
\hline $56-60$ & & & $X_{9,3}$ & $X_{9,4}$ & $X_{9,5}$ & $\mathrm{X}_{9,6}$ & $X_{9,7}$ & $X_{9,8}$ & $X_{9,9}$ & $X_{9,10}$ & & & & & & & \\
\hline 61-65 & $x_{10,1}$ & $\mathrm{X}_{10,2}$ & $X_{10,3}$ & $\mathrm{X}_{10,4}$ & $X_{10,5}$ & $\mathrm{X}_{10,6}$ & $X_{10,7}$ & $\mathrm{X}_{10,8}$ & & & & & & & & & \\
\hline 66-69 & $X_{11,1}$ & $X_{11,2}$ & $X_{11,3}$ & $X_{11,4}$ & $X_{11,5}$ & $X_{11,6}$ & $X_{11,7}$ & $X_{11.8}$ & & & & & & & & & \\
\hline
\end{tabular}

Estimate $x_{i, j}$ as average of two adjacent cells (same row)(within-age-group adjustment)

Estimate $x_{i, j}$ by assuming that the ratio compared to the adjacent age group is the same in the two five-year groups of birth years within a ten-year cohort

Drop observation 
All figures of cohort trends in the paper give the adjusted shares. They do not display any confidence intervals, because it is not possible to derive these for the adjusted shares. If one calculates the confidence intervals for the estimates before the adjustment they turn out to be very narrow due to the large sample sizes. The only exception to this occurs when we compare different ethnic groups, where we will address the significance of differences in the text.

\section{Figure 3: Shares of men living with an own dependent child aged 18 or below,} by age and birth cohort

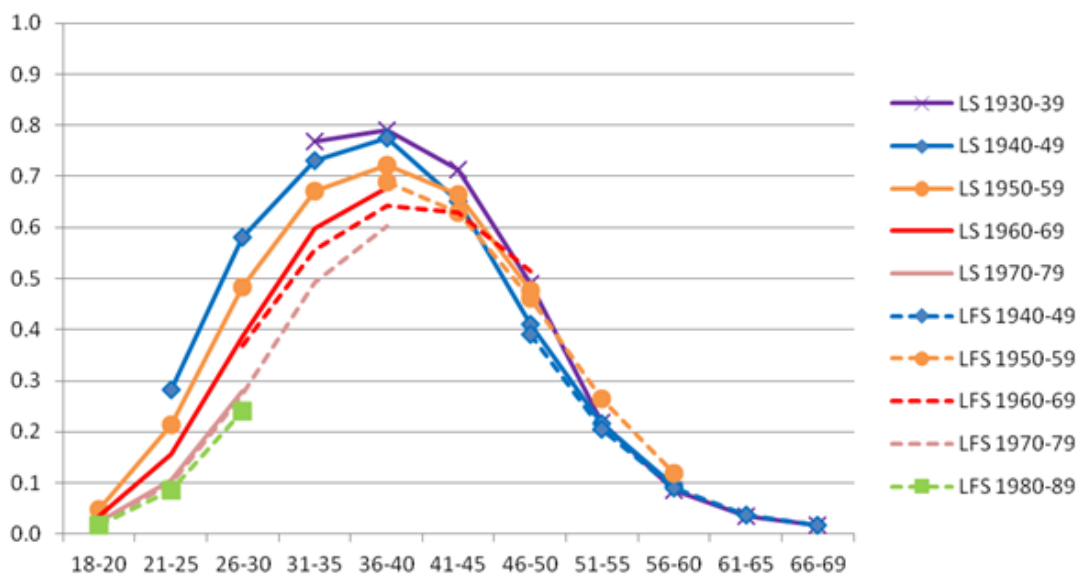

\section{Results}

\subsection{Co-residence with a dependent child up to 18 years of age}

Figure 3 gives the adjusted percentage of men living with a dependent child aged 18 or below for five-year age groups and ten-year birth cohorts. Over successive cohorts, the incidence of living with a dependent child dropped at younger ages; 58 per cent of the 26 to 30 year olds in the 1940-49 cohort lived with a child, compared to 48,39 and 28 per cent in the following cohorts, according to the LS. The LFS data for the 1980-89 cohort indicate a deceleration of the decreasing trend of living with a child at young ages. 
For men aged 31 to 45, the main pattern is one of declining rates of father-child co-residence over cohorts. In all cohorts, the rates peaked in the age group from 36 to 40 - in the 1930-39 cohort at 79 per cent, dropping to 77 per cent in the 1940-49 cohort and to 72 per cent in the 1950-59 cohort. According to the LFS data, the trends continued in the 1960-69 cohort with a peak at 64 per cent. For the 1970-79 cohort, the maximum share cannot be determined yet.

Because of the increase in cohabitation and separation rates since the 1970s, one might have expected that the changes might have accelerated in the younger cohorts. However, Figure 3 provides no support for an acceleration in the decline in father-child co-residence from the 1940-49 cohort onwards when looking at men in their 30s. Compared to the 1940-49 cohort, there is a modest increase in the rates of father-child co-residence among men in their late forties and, for the 1950-59 cohort, also for men in their fifties. ${ }^{7}$ Apart from the small increase at higher ages, Figure 3 supports

\section{hypothesis 1 .}

Overall, the figure shows a dramatic change of father-child co-residence of men in their twenties, supporting hypothesis 3 . In the most recent cohorts, only about a quarter of young men lived with an own child before they reached age 30 . As there is only a weak increase in the shares of men living with their children at higher ages in the most recent cohorts, the experience of fatherhood is increasingly concentrated in men's third and fourth decades of life.

\subsection{Co-residence with three or more own dependent children}

Compared to small families, a larger number of children arguably put particular demands on fathers. Figure 4 gives the adjusted shares of men living with three or more dependent children. In all cohorts, this experience was most widespread among men in their thirties, where it reached 28 per cent in the 1930-39 cohort. At 20 to 13 per cent, the numbers were considerably lower in all younger cohorts, confirming hypothesis 2. Overall, the figure shows a decrease in the prevalence of being a father of a relatively large family. This might have reduced the risk of poverty and provided more scope for being involved in all children's lives.

\footnotetext{
${ }^{7}$ According to our definition of dependent children, children up to age 18 are included if they are in full-time education. The rising rates of father-child co-residence at higher ages could therefore be an effect of increasing levels of educational enrolment of the children, which might have compensated for otherwise falling shares of parent-child co-residence. To assess the possible impact of educational expansion, we have calculated the shares of co-residence with a child aged 15 or younger (results not shown). The relative position of cohort-specific shares of parent-child co-residence of men in their forties and older remained similar to those in Figure 3.
} 
Figure 4: Adjusted shares of men living with 3+ own dependent children up to age 18, by age and birth cohort

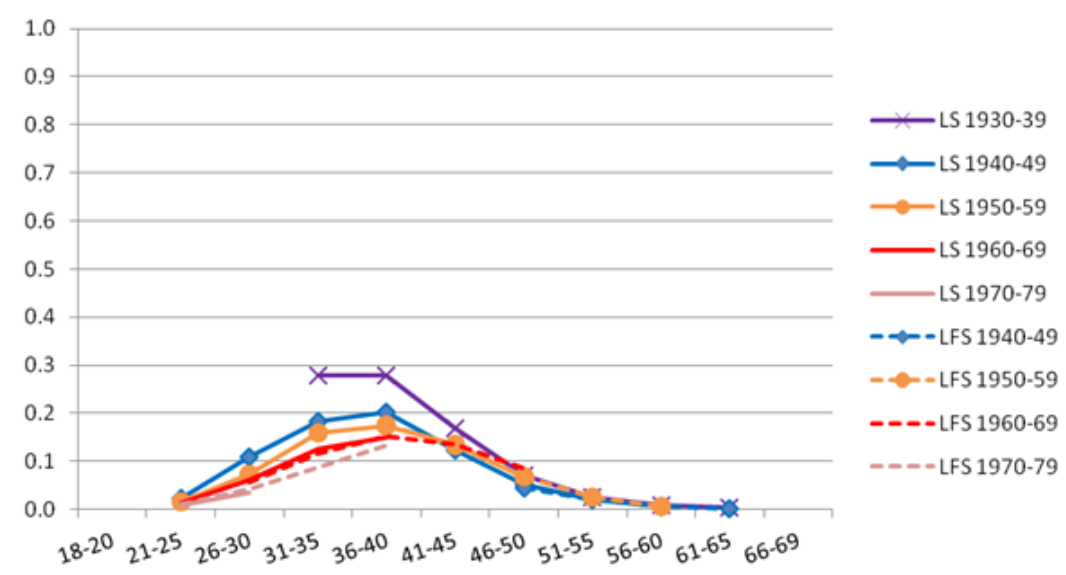

\subsection{Differences by level of education}

Figures $5 \mathrm{a}$ to $5 \mathrm{c}$ give the cohort-specific tally of men who lived with a dependent child aged 18 or younger separately for the three levels of education. They show a surprising degree of similarity in pattern across different educational groups. In all groups, the incidence of living with a child decreased considerably at younger ages over successive cohorts, and, for all educational groups, the peak rates of father-child co-residence came down. These peak rates were very similar for men with a degree and men with a subdegree level of education, and slightly lower among men with a low level of education. There are, however, also some clear differences between the educational groups. In the older cohorts, men with no qualifications displayed higher rates of father-child coresidence at younger ages than the other two educational groups. Their numbers approached those of the men with sub-degree qualifications in the younger cohorts. Men with a degree had the lowest level of father-child co-residence in this age group. 
Figure 5a: Proportions of men with no educational qualifications of living with an own dependent child aged 18 or younger, by age and cohort

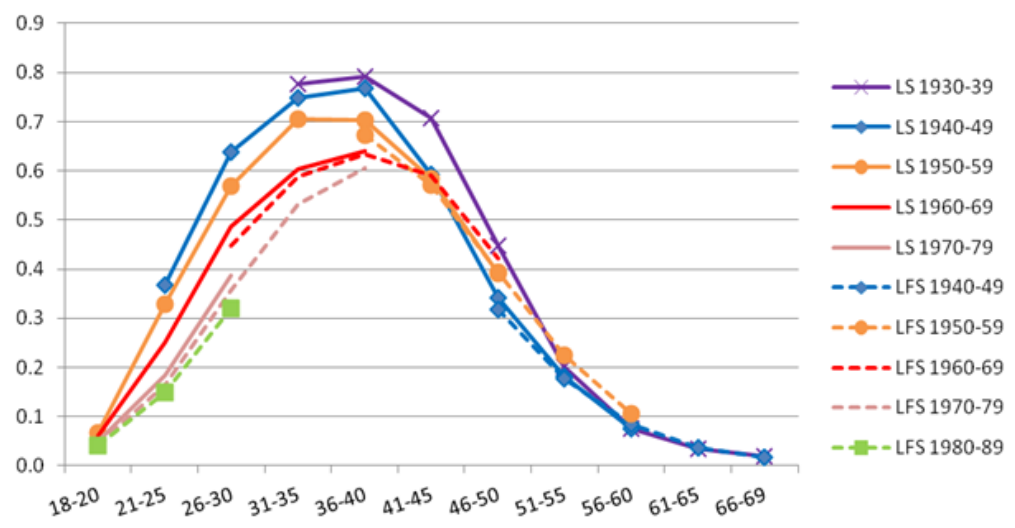

Figure 5b: Proportions of men with sub-degree educational level of living with an own dependent child aged 18 or younger, by age and cohort

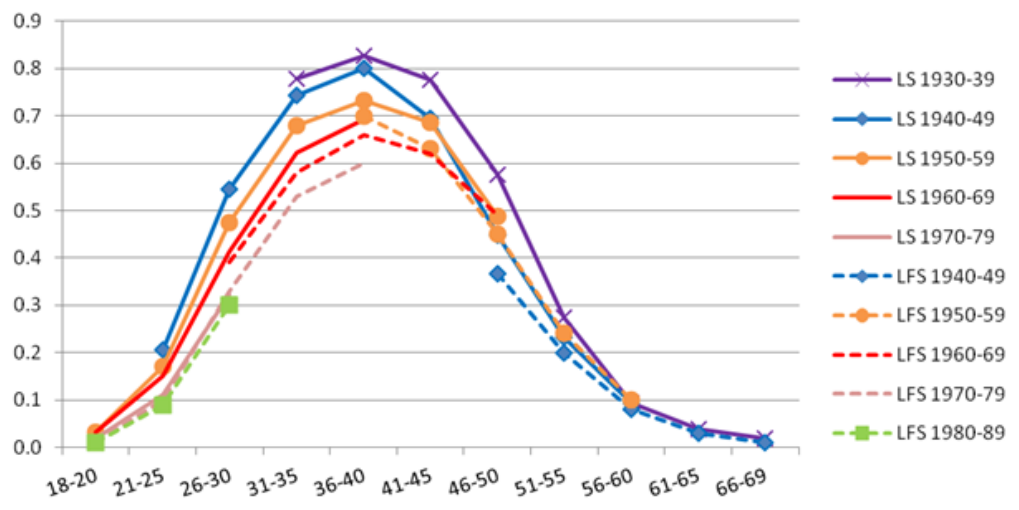




\section{Figure 5c: Proportions of men with a degree of living with an own dependent child aged 18 or younger, by age and cohort}

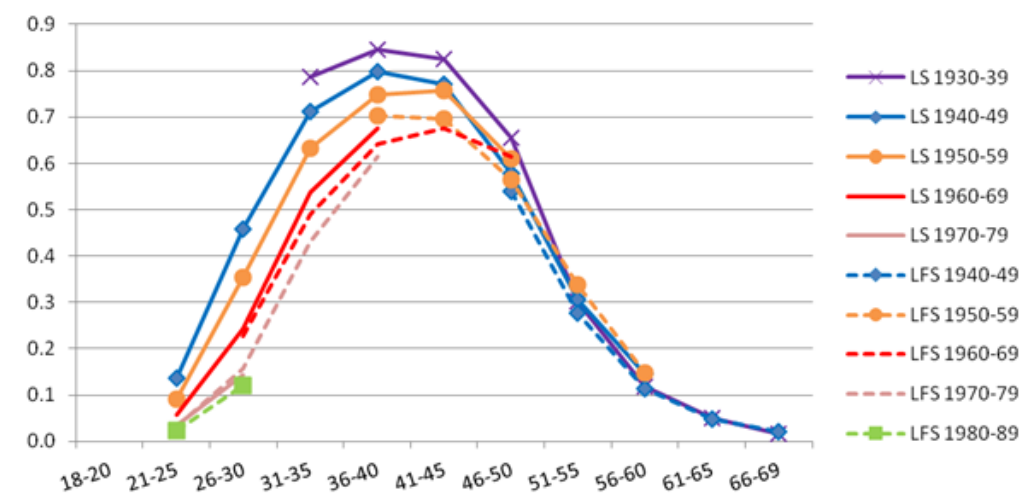

Importantly, the data does not indicate that father-child co-residence decreased more strongly among less educated men than among other men. For example, the drop in father-child co-residence at ages 36-45 was roughly the same in all educational groups; at ages 31-35 the drop was steeper for men with a degree than for the other two educational groups. For ages 46 and above, the shares of co-residence increased for all three educational groups. Therefore, the findings do not support the contention that less educated men have evidenced lower levels of father-child co-residence due to particularly high levels of uncertainty.

The figures also show that father-child co-residence has increased at higher ages. This is most clearly visible for men with no qualifications and men with a degree, in their forties and fifties. This trend towards later fatherhood is also reflected in a shift in the age when the incidence of co-residence reached their maximum among men with a degree: it occurred at ages 36 to 40 in the older cohorts and moved to age 41 to 45 for men in the younger cohorts. For men without a degree, the peaks remained at ages 36 to 40 in all cohorts. These observations do not rule out the possibility that more men with sub-degree qualifications have become fathers at greater ages. However, in this group such an increase would have been more strongly offset by other trends that led to lower rates of father-child co-residence. The similarity of the overall pattern provides partial support for hypothesis 4. 


\subsection{Differences by ethnicity}

To examine variations in father-child co-residence by ethnicity, we apply a slightly different strategy. The composition of the ethnic groups was affected by different and changing immigration pathways into Britain, which is reflected in the patterns of fatherchild co-residence. For example, the levels of father-child co-residence among Pakistani and Bangladeshi men of the older cohorts were very low (Figure 6). In their thirties and forties, a much smaller share of these men lived with their children than did men in other ethnic groups, but the numbers increased in each successive cohort. It is fair to assume that these differences reflect different circumstances of immigration to Britain, as these almost exclusively male migrants left their wives and children back at home, or married at a greater age (Peach 1996).

\section{Figure 6: Adjusted numbers of Pakistani/Bangladeshi men living with an own dependent child; by cohort}

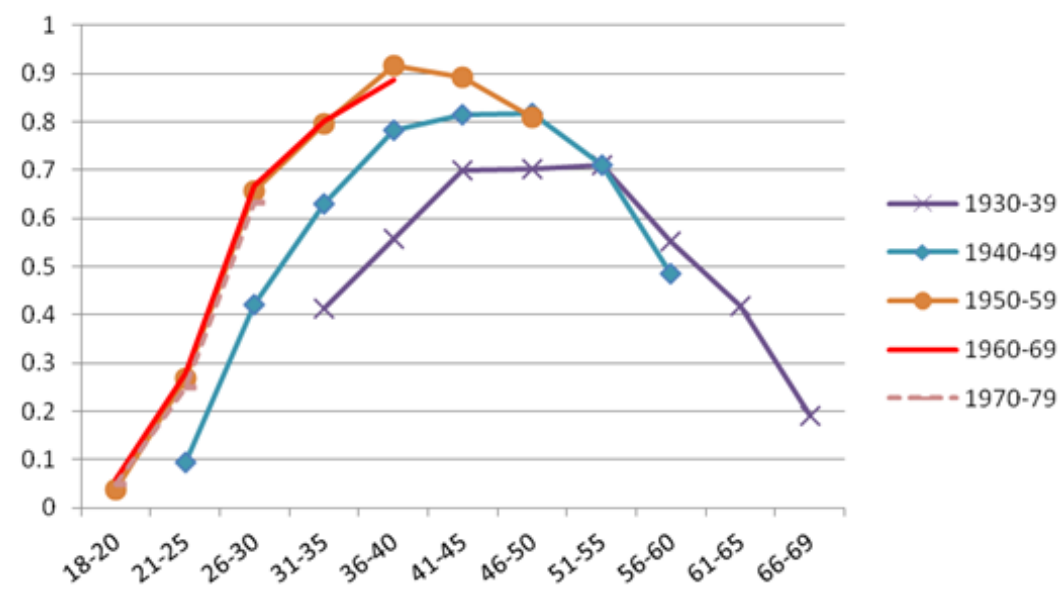

Instead of studying cohort changes for each ethnic group, we examine whether the diversity between ethnic groups changed in successive cohorts. Figures $7 \mathrm{a}$ and $\mathrm{b}$ show the rates of parent-child co-residence by ethnicity in the 1940-49 and 1960-69 cohorts. For men in both cohorts, there is a considerable variation in father-child co-residence between ethnic groups. Among men in the older birth cohort (Figure 7a), White men had the lowest levels of co-residence with their children and Asian groups had the 
highest levels. To assess the significance of these differences, one can inspect the confidence intervals of the unadjusted numbers (not shown), according to which, the rates for men of Indian origin are significantly higher than those for White men from age 31 onwards, and for men from Pakistani or Bangladeshi origin from age 41 and higher. Men of Pakistani or Bangladeshi origin stood out by having lower levels of father-child co-residence at younger ages, which was partly compensated by high rates of father-child co-residence when the cohort members were 50 years old or older. For both groups of men from Black origins, the numbers estimated from the two data sources differ considerably, but all counts were above those of White men. When looking at the confidence intervals for unadjusted shares derived from the LS (not shown), the rates of father-child co-residence of men from Black-Caribbean origin were significantly higher than those for White men in the age groups 26 to 30 and all ages above age 40. For men of Black-African origin, the rates were lower than those of White men in the age group 26 to 30, and higher than those of White men at all ages from age 46 and older. In the other age groups there were no significant differences compared to the numbers for White men.

Among men born twenty years later (cf. Figure $7 b$ ), there are still considerable differences in the proportions of father-child co-residence. They differed by as much as 30 per cent in the LS and 37 per cent in the LFS. Men of Pakistani and Bangladeshi origin have 'overtaken' all other ethnic groups at young ages in the extent to which they live with their children. This group displays higher rates of father-child co-residence than all other groups at all ages. When looking at the confidence intervals around the unadjusted groups, the numbers for Pakistani and Bangladeshi men are significantly higher than those of White men from age 26 onwards, and those of Indian men are significantly higher than those of White men from age 30 onwards. There is some indication that the relative position of Black-Caribbean men had changed compared to older cohorts. According to the LS, their levels of co-residence were slightly below those of White men, which is significant in the above sense only for the age group 36 to 40. According to the LFS their levels of co-residence were well below the other groups, and significantly smaller than those of White men. In the 1970-79 birth cohort (not shown) the difference between Pakistani and Bangladeshi men on the one side and all other groups on the other side has become more pronounced.

In conclusion, men's co-residence with their children varied considerably between ethnic groups. An overwhelming majority of Pakistani and Bangladeshi men lived with their children at mid-age. The analyses support hypothesis 5 with Figure $7 \mathrm{~b}$ depicting an intermediate position for men of Indian origin between men of Bangladeshi and Pakistani origin and men of White origin. In the 1970-79 cohort (not shown), the counts for men of Indian origin were very close to those of White origin and only the 
Henz: Long-Term Trends of Men's Co-residence with Children in England and Wales

Bangladeshi/Pakistani group stands out. As discussed above, the LFS data support hypothesis 6 but not the LS data.

Figure 7a: Adjusted proportions of men born in 1940-49 living with an own dependent child; by age and ethnicity
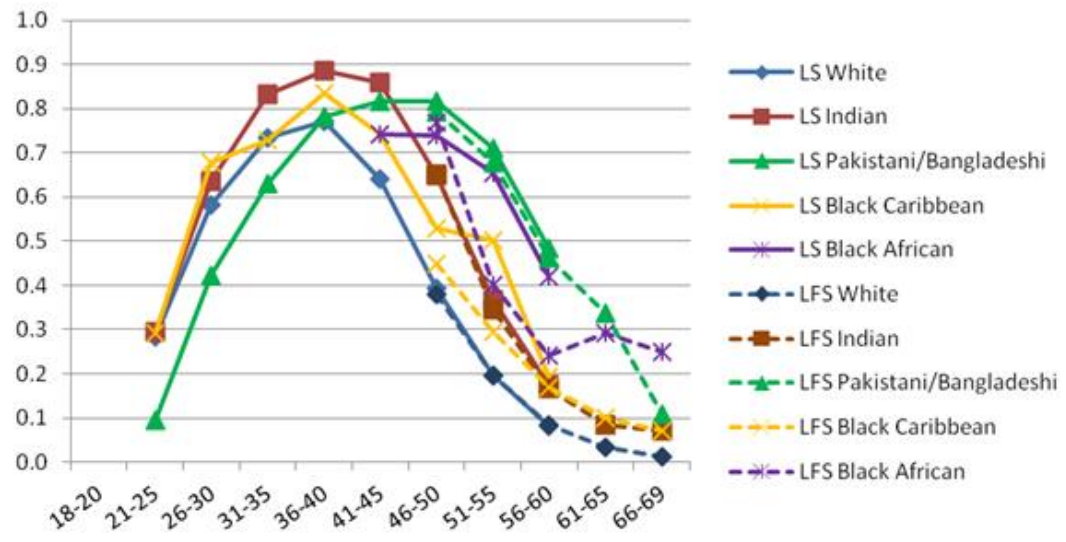

Figure 7b: Adjusted counts of men born in 1960-69 living with an own dependent child; by age and ethnicity
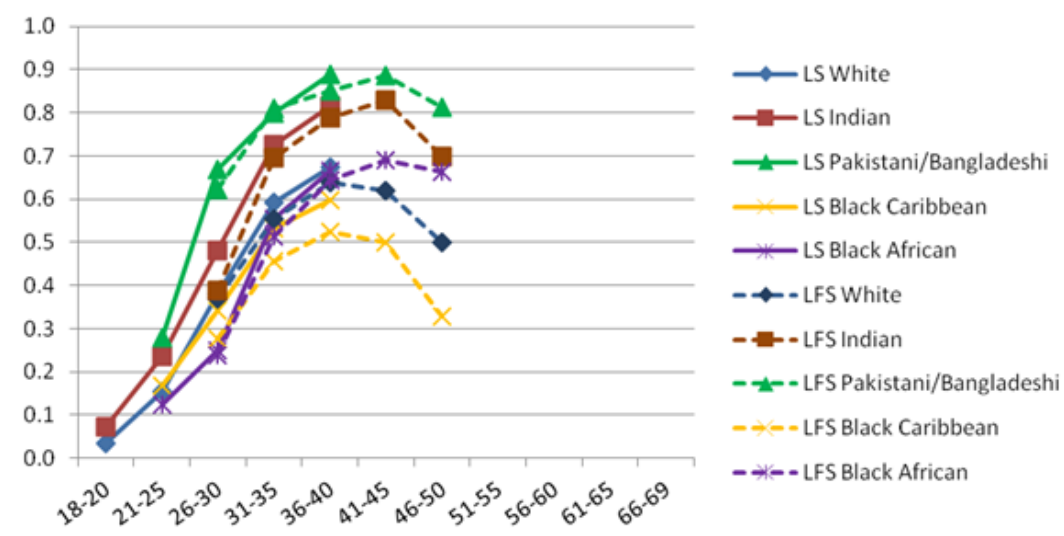


\section{Conclusions}

The analyses have shown that the complex interplay of trends in childlessness and family size, the timing of fatherhood and men living away from their children led to a pronounced drop in father-child co-residence at younger ages, a weaker decrease among men in their thirties and stability or even a small increase among men at higher ages, in England and Wales. Also the experience of living with several children has become less common, emphasizing that not just the prevalence of fatherhood has changed but also the demands associated with the role of father.

The change in father-child co-residence was particularly dramatic among men in their twenties. Living with one's child before age 30 has turned from a majority to a minority experience. The education-specific figures show that the drop was steepest among highly educated men, and that the growth of this particular group over successive cohorts has exacerbated the aggregated trend. Early observations for the 1980-89 cohort suggest that the decreasing trend of father-child co-residence at younger ages is beginning to slow down. The drop in father-child co-residence in young adulthood was in line with expectations of growing childlessness, the effects of a longer stay in the educational system, and more drawn-out processes of establishing a partnership and career.

It would be misleading to generalize this strong decline in father-child coresidence to later phases in men's life courses. The cohort differences between men in their thirties were negative, but considerably smaller than those at younger ages. Beyond age 40, the decline stopped and the figures even showed a moderate increase of men in their late forties living with their children. Together with the switch of the peak incidence of co-residence to an older age group among highly educated men, these trends are proof of a change in the structure of men's life-courses. Co-residential fatherhood has shifted away from young adulthood and is more concentrated in midage. The increase of the shares at higher ages is small. Men might have the physical ability to postpone fatherhood to higher ages, but rather few men have opted for it, pointing to the existence of barriers to becoming a father at higher ages. Interestingly, the trend to late fatherhood is most clearly visible among the less-educated men (Figure 5a). We find the diversity of 'late' fathers intriguing, and call for more research into the pathways and the barriers to older fatherhood.

The comparison between the three educational groups has proven wrong suggestions that the decline in father-child co-residence was particularly strong for men with a low level of education. The studies for the US (Eggebeen 2002) and Norway (Skrede 2005) found that less-educated men displayed the lowest levels of father-child co-residence. In England and Wales, their shares were among the highest at younger ages and only slightly lower in mid-age than for the other two groups. The finding calls 
into question the assumed high importance of economic uncertainty for men with low educational attainment entering co-residential fatherhood in England and Wales. More generally, the considerable similarity of the education-specific patterns of father-child co-residence in England and Wales raises the question of whether in Britain, family patterns and social classes might not align strongly for men. Such a finding would reduce concerns about a polarization of society. However, before any firm conclusion can be reached, more research is needed, particularly analyses into class differences in living with children instead of differences by educational level. Unfortunately the LS does not provide consistent measures of social class over time.

The comparison between ethnic groups has documented the considerable variations in father-child co-residence between men of different ethnic origins in England and Wales. Most of these differences have decreased in more recent cohorts, but a considerable contrast remains between the nearly universal presence of children in the lives of men from Pakistani and Bangladeshi origin compared to the other ethnic groups. In contrast to our expectations, the analyses did not show particularly low levels of father-child co-residence among men of Black African and Black Caribbean origin. Only according to the LFS, living with one's child has ceased to be a majority experience for Black-Caribbean men of any age in the more recent cohorts, but the observation is in contrast to the LS calculations that put the shares of Black-Caribbean men close to those of White men. On this particular issue we tend to regard the LS result more valid because of the high quality of the 2001 census data. The finding is particularly interesting as it demonstrates the dangers of transferring patterns observed for women to men, in this case from the high levels of lone motherhood among women of Caribbean origin to high levels of men not living with any own children. It underlines the need for more research on family formation processes from the perspective of men.

The study has several limitations. The patterns of father-child co-residence among ethnic minorities in older cohorts could be affected by selectivity bias, as these men were only included in the study if they were identified in the 1991 or 2001 censuses. Furthermore, although the data are the best available for the analysis, both data sets had to resort to auxiliary strategies for specifying the relationship between adults and children in the household in the older survey waves. In addition, the data did not capture more fluid living arrangements in which fathers 'flow' in and out of the household, or children move between their separated parents' homes. However, these shortcomings should not distract from the paper's merits in addressing a gap in the literature regarding longitudinal information about English and Welsh men living with children, and suggesting a strategy for carrying out a synthetic cohort analysis with census data. 
Finally let us return to the concerns about 'shrinking fatherhood'. Does our study show a sufficiently strong decline to justify this notion for England and Wales? In contrast to the studies for the United States, no particular group of men emerged of whom at any age only a minority lived with a child. Another possible point of reference is the trend for women. Rates of mother-child co-residence have also decreased but from a higher level and at a slower pace - in our data the peak shares dropped from 86 to 80 per cent among women compared, to 79 to 64 per cent for men. The continuous rise of the gender gap during our observation period lends some support for the emergence of more extreme divergences in men and women living with their children in England and Wales. Our data show few signs of a slowing down of the decreasing trends in father-child co-residence. Therefore, the notion of 'shrinking fatherhood' might indeed be an appropriate description for fatherhood in England and Wales. However, the low levels of mother-child co-residence among women with a degree show that an increasingly child-free life style is not limited to men. Progress in our understanding of the underlying processes is most likely if we do not focus on men and women overall but study the differences faced by particular socio-demographic groups of women and men.

\section{Acknowledgements}

The permission of the Office for National Statistics to use the Longitudinal Study is gratefully acknowledged (clearance number 30127), as is the help provided by Neil Smith and Rachel Stuchbury from the Centre for Longitudinal Study Information and User Support (CeLSIUS). The Labour Force Surveys were carried out on behalf of the Office for National Statistics, and were accessed through the Economic and Social Data Service. The author worked on some of the analyses during her stay at the German National Educational Panel Study at Bamberg University, Germany. Earlier versions of the paper were presented at the Annual Conference of the British Society for Population Studies and the European Population Conference. The author alone is responsible for the calculations and the interpretation of the data. 


\section{References}

Amato, P.R. (2000). The consequences of divorce for adults and children. Journal of Marriage and Family 62(4): 269-1287. doi:10.1111/j.1741-3737.2000.01269.x.

Barnes, G.G., Thompson, P., Daniel, G., and Burchardt, N. (1997). Growing up in stepfamilies. New York: Clarendon Press.

Beaujouan, E. (2012). Repartnering in France: The role of gender, age and past fertility. Advances in Life Course Research 17(2): 69-80. doi:10.1016/j.alcr.2012.03.001.

Berrington, A. (1994). Marriage and family formation among the white and ethnic minority populations in Britain. Ethnic and Racial Studies 17(3): 517-546. doi:10.1080/01419870.1994.9993837.

Berrington, A. and Diamond, I. (1999). Marital dissolution among the 1958 British Birth Cohort: The role of cohabitation. Population Studies 53(1): 19-36. doi:10.1080/00324720308066.

Berthoud, R. (2005). Family formation in multicultural Britain: diversity and change. In: Loury, G.C., Modood, T., and Teles, S.M. (eds.) Ethnicity, social mobility and public policy. Cambridge: Cambridge University Press: 222-261.

Bhrolchain, M.N. and Beaujouan, E. (2012). Fertility postponement is largely due to rising educational enrolment. Population Studies 66(3): 311-327. doi:10.1080/ 00324728.2012.697569.

Billari, F.C., Liefbroer, A.C., and Philipov, D. (2006). The postponement of childbearing in Europe: Driving forces and implications. Vienna Yearbook of Population Research 4(1): 1-17.

Blackwell, L., Lynch, K., Smith, J., and Goldblatt, P. (2003). Longitudinal Study 19712001: Completeness of census linkage. London: Office for National Statistics

Blossfeld, H-P., Klijzing, E., Mills, M., and Kurz, K. (eds). (2005). Globalization, uncertainty, and youth in society. London: Routledge.

Bradshaw, J., Stimson, C., Skinner, C., and Williams, J. (1999). Absent fathers? London and New York: Routledge. doi:10.4324/9780203252376.

Chan, T.W. and Halpin, B. (2003). Union dissolution in the United Kingdom. International Journal of Sociology 32(4): 76-93. 
Coleman, D.A., Compton, P., and Salt, J. (2002). Demography of migrant populations: The case of the United Kingdom. In: Haug, W., Compton, P., and Courbage, Y. (eds.). The demographic characteristics of immigrant populations. Strasbourg: Council of Europe Publishing: 497-552.

Coleman, D.A., and Dubuc, S. (2010). The fertility of ethnic minorities in the UK, 1960s-2006. Population Studies 64(1):19-41. doi:10.1080/00324720903391201.

Coleman, D.A. and Smith, M.D. (2005). The projection of ethnic minority populations: problems and data needs. University of Oxford: Department of Social Policy and Intervention (No. 55).

Daly, M. (2005). Changing family life in Europe: Significance for state and society. European Societies 7(3): 379-398. doi:10.1080/14616690500194001.

Eggebeen, D.J. (2002). The changing course of fatherhood. Journal of Family Issues 23(4): 486-506. doi:10.1177/0192513X02023004002.

Eggebeen, D.J. and Knoester, C. (2001). Does fatherhood matter for men? Journal of Marriage and Family 63(2): 381-393. doi:10.1111/j.1741-3737.2001.00381.x.

Eggebeen, D.J. and Uhlenberg, P. (1985). Changes in the organization of men's lives: 1960-1980. Family Relations 34(2): 251-257. doi:10.2307/583899.

Ermisch, J. (2005). The Puzzling Rise in Childbearing Outside Marriage. In: Heath, A.F., Ermisch, J., and Gallie, D. (eds.). Understanding Social Change. Oxford: British Academy: 22-53. doi:10.5871/bacad/9780197263143.003.0002.

ESDS (2012). Ethnicity in the LFS, consistent over time. Mimeo obtained from the UK Data Service, February 2014.

Francesconi, M. and Golsch, K. (2005). The process of globalization and the transition to adulthood in Britain. In: Blossfeld, H-P., Klijzing, E., Mills, M., and Kurz, K. (eds). Globalization, uncertainty, and youth in society. London: Routledge: 249-276.

George, L.K. and Gold, D.T. (1991). Life course perspectives on intergenerational and generational connections. In: Pfeifer, S.K. and Sussman, M.B. (eds.): Families: Intergenerational and generational connections, New York and London: The Haworth Press: 67-88.

Goldscheider, F.K., Hogan, D. and Bures, R. (2001). A century (plus) of parenthood. History of the Family 6(4): 477-494. doi:10.1016/S1081-602X(01)00087-2. 
Goldscheider, F.K., and Sassler, S. (2006). Creating stepfamilies: Integrating children into the study of union formation. Journal of Marriage and Family 68(2): 275-291. doi:10.1111/j.1741-3737.2006.00252.x.

Haskey, J. (1996a). The ethnic minority populations of Great Britain: Their estimated sizes and age profiles. Population Trends 84: 33-39.

Haskey, J. (1996b). Population review (6): Families and households in Great Britain. Population Trends 85: 7-24.

Haskey, J. (1997). Population review: (8): The ethnic minority and overseas-born populations of Great Britain. Population Trends 88: 12-30.

Hattersley, L., and Creeser, R. (1995). The Longitudinal Study, 1971-1991: History, organisation and quality of data. London: H.M.S.O.

Hogan, D. and Goldscheider, F.K. (2001). Men's flight from children in the U.S.: A historical perspective. In: Hofferth, S.L. and Owens, T.J. (eds.). Children at the millennium: Where have we come from, where are we going?. Amsterdam and New York: Elsevier: 173-191.

Jeffries, J., Berrington, A., and Diamond, I. (2000). Childbearing following marital dissolution in Britain. European Journal of Population 16(3): 193-210. doi:10.1023/A:1026529300659.

Jensen, A.-M. (1995). Gender gaps in relationships with children: closing or widening. In: Mason, K.O. and Jensen, A.-M. (eds.). Gender and family change in industrialized countries. Oxford: Clarendon Press: 223-242.

Jensen, A.-M. (1998). Partnership and parenthood in contemporary Europe: A review of recent findings. European Journal of Population 14(1): 89-99. doi:10.1023/ A:1005990530876.

Jensen, A.-M. (1999). Partners and parents in Europe: A gender divide. Comparative Social Research 18 1-29.

Keizer, R., Dykstra, P.A., and Poortman, A.-R. (2010). Life outcomes of childless men and fathers. European Sociological Review 26(1): 1-15. doi:10.1093/esr/jen080.

Kiernan, K. (1989). Who remains childless? Journal of Biosocial Science 21(4): 387-398. doi:10.1017/S0021932000018125.

King, R.B. (1999). Time spent in parenthood status among adults in the United States. Demography 36(3): 377-385. doi:10.2307/2648060. 
Kneale, D. and Joshi, H. (2008). Postponement and childlessness: Evidence from two British cohorts. Demographic Research 19(58): 1935-1968. doi:10.4054/ DemRes.2008.19.58

Lamb, M.E. (2010). The role of the father in child development, New York: Wiley.

Lesthaeghe, R. (1995). The second demographic transition in Western Countries: an interpretation. In: Mason, K.O. and Jensen, A.-M. (eds.). Gender and family change in industrialized countries. Oxford: Clarendon Press: 17-62.

O'Leary, L., Natamba, E., Jefferies, J., and Wilson, B. (2010). Fertility and partnership status in the last two decades. Population Trends 140(1): 5-35. doi:10.1057/ pt.2010.10.

ONS (2009) Births in England and Wales 2008. Population Trends 138(1): 85-89. doi:10.1057/pt.2009.51.

ONS (2012a). The ONS Longitudinal Study [electronic resource]. http://www.ons.gov.uk/ons/guide-method/user-guidance/longitudinalstudy/index.html.

ONS (2012b). Quality of Census-to-Census linkage (Quality of linkage between 1971 and 1981 Censuses) [electronic resource]. http://www.ons.gov.uk/ons/guidemethod/user-guidance/longitudinal-study/data-quality/quality-of-census-tocensus-linkage/index.html.

ONS (2012c). Divorces in England and Wales [electronic resource]. http://www.ons.gov.uk/ons/dcp171778_291750.pdf.

ONS (2013). Cohort fertility, England and Wales 2011 [electronic resource]. http://www.ons.gov.uk/ons/dcp171778_299058.pdf.

Peach, C. (1996). Ethnicity in the 1991 census. Volume two: The ethnic minority populations of Great Britain. London: H.M.S.O.

Platt, L. (2009). Ethnicity and family: relationships within and between ethnic groups. London: Equality and Human Rights Commission.

Rendall, M.S., Clarke, L., Peters, H.E., Nalini R., and Verropoulou, G. (1999). Incomplete reporting of men's fertility in the United States and Britain: A research note. Demography 36(1): 135-144. doi:10.2307/2648139.

Rupp, M. (2009). Zukunft ohne Kinder. In: Burkart, G. (ed.) Zukunft der Familie. Prognosen und Szenarien. Opladen: Budrich: 213-236. 
Henz: Long-Term Trends of Men's Co-residence with Children in England and Wales

Skrede, K.. (2005). Foreldreskap $i$ forandring - farre menn blir fedre. http://kilden.forskningsradet.no/c35640/artikkel/vis.html?tid=36613.

Steele, F., Joshi, H., Kallis, C., and Goldstein, H. (2007). Changes in the relationship between the outcomes of cohabiting partnerships and fertility among young British women: Evidence from the 1958 and 1970 Birth Cohort Studies. Centre for Longitudinal Studies. London: Centre for Longitudinal Studies, Institute of Education, University of London.

van de Kaa, D. (1987). Europe's Second Demographic Transition. Population Bulletin 42(1): 1-57. 


\section{Appendix}

Figure A1: Unadjusted shares of men living with an own dependent child aged 18 or below, by age and birth cohort

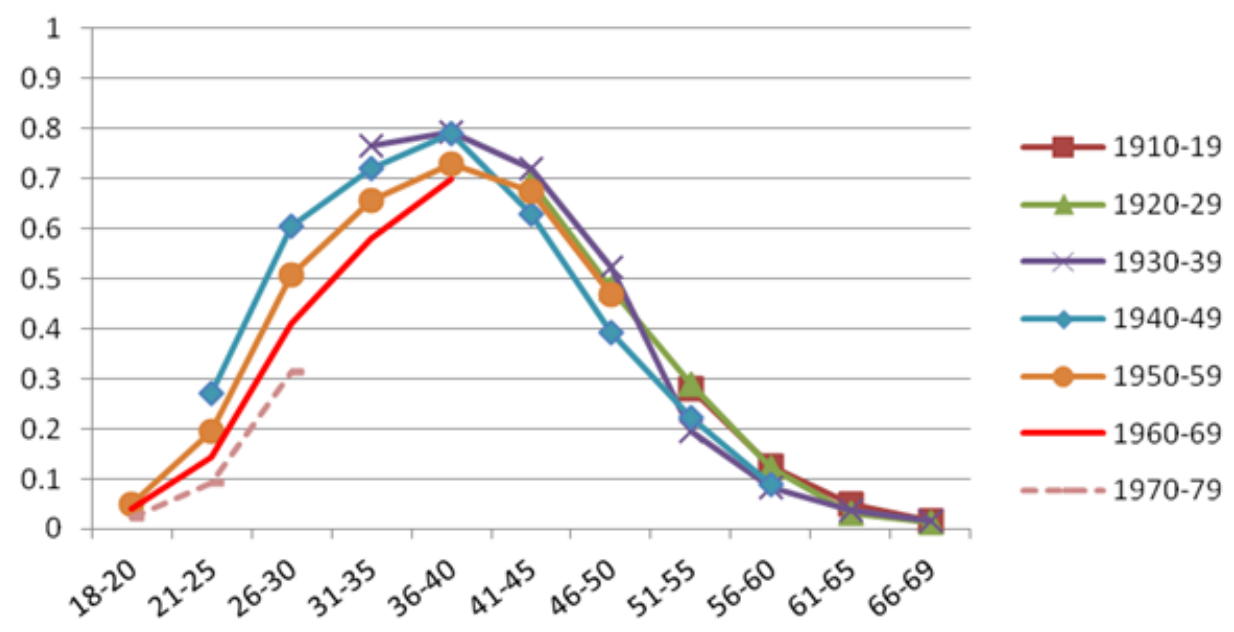


Henz: Long-Term Trends of Men's Co-residence with Children in England and Wales 